\title{
The Role of Product Differentiation and Word of Mouth on Purchase Decision of Creative Industrial Products
}

\author{
Hikmah Hikmah ${ }^{1}$, Andalan Tri Ratnawati ${ }^{1}$, Susetyo Darmanto ${ }^{1, *}$ \\ ${ }^{1}$ Fakultas Ekonomika dan Bisnis, Universitas 17 Agustus 1945 Semarang, Semarang, Indonesia \\ *Corresponding author. Email: susetyodarmanto@untagsmg.ac.id
}

\begin{abstract}
This study aims to analyse the effect of word of mouth and product differentiation on purchasing decisions for creative industry handicraft products at the waste bank in Semarang City. The research population is a waste bank in Semarang City that produces and sells handicraft products. The sampling technique used purposive sampling, obtained as many as 33 respondents. This study used multiple linear regression analysis with SPSS tools. The results showed that word of mouth and product differentiation had a positive and significant effect on purchasing decisions for creative industry handicraft products. Local governments and the public are expected to pay more attention to and help promote and develop creative industries produced by waste banks.
\end{abstract}

Keywords: creative industry, craft, word of mouth, product differentiation, purchase decision, waste bank.

\section{INTRODUCTION}

Creative industry is defined as an industry that has authenticity in creativity, skills and individual talents that have the potential for prosperity and creation through the exploitation of intellectual property [1]. Creative economy which implemented as creative industry in Indonesia has promising potential, as evidenced by the contribution to gross domestic product in 2020. Based on Focus Economy Outlook 2020 data, the creative economy contributed IDR 1,100 trillion, this figure increased from 2017 and 2018, which was only IDR 1,000 trillion and Rp1.105 trillion [2].

One type of creative industry that has become the leading sector in Semarang City is craft which is mostly produced through waste bank management [3]. A waste bank is a place for dry waste management through the $3 \mathrm{R}$ concept (reduce, reuse, recycle) so that it has economic value [4]. Through the waste bank, various kinds of creative industries are produced from craft products which are then marketed to the wider community, including to local governments. In its development, handicrafts produced from waste banks face problems that are not easy in terms of marketing, especially from the aspect of promotion and products, so research is needed regarding the factors that influence purchasing decisions for handicrafts produced by waste banks.

Word of mouth and product differentiation are efforts that can be made to increase product sales through promotional efforts and product diversity. Word of mouth is one of the promotional media through personal communication about a product with the closest known people [5]. Meanwhile, product differentiation is all activities carried out to create differences that aim to provide added value to the product to consumers [6].

However, several previous studies show that there are still differences in findings about the effect of word of mouth and product differentiation on product purchasing decisions. The previous studies prove that word of mouth has a significant effect on purchasing decisions [7, 8], while the other conclude that word of mouth has no significant effect on purchasing decisions [9]. Many research prove that product differentiation has a significant effect on purchasing decisions $[10,11]$, while prove that product differentiation has no effect on purchasing decisions [12].

Underlying these problems, this study aims to analyse the effect of word of mouth and product differentiation on purchasing decisions for handicrafts 
produced by the creative industry in the waste bank of Semarang City.

\section{LITERATURE REVIEW}

\subsection{Word of Mouth and Purchasing Decisions}

Word of mouth is a marketing activity carried out on a product so that consumers talk about, promote and are willing to sell our products to others [13]. Word of mouth is a way of communicating by word of mouth from one customer to another due to the positive experience in consuming the product [14]. According to Sernovitz et al, several things that can be done so that other people are willing to talk about our products are: be interesting (creating an interesting product that is different from other similar products so that it becomes interesting to discuss), make people happy (word of mouth will effective if the company can make consumers happy, for example in terms of product quality and customer service), earn trust and respect (an effort to gain trust and respect from customers) [15]. The results of research conducted by Finanda and Wiwaha on the influence of word of mouth on purchasing decisions for beauty products at Salon Miloff Beauty Bar proves that word of mouth has a positive and significant effect on purchasing decisions [7]. Other research conducted also proves that word of mouth has a positive and significant effect on purchasing decisions [16]. Underlying this, the proposed hypothesis is:

H1: Word of mouth has a positive and significant effect on purchasing decisions

\subsection{Product Differentiation and Purchasing Decisions}

Product differentiation is a company's effort to offer its products to customers with better value, faster and cheaper than competing products [6]. Product differentiation is an important strategy besides price, it is effective when business development requires products that are superior to competitors [10]. The results of research conducted by Rahman and Suhayani on the effect of product differentiation on purchasing decisions for Yamaha Mio products in Langsa City prove that product differentiation has a positive and significant effect on purchasing decisions [11]. Previous research also proves that product differentiation has a positive and significant effect on purchasing decisions $[10,17]$. Based on this, the second hypothesis proposed is:

H2: Product differentiation has a positive and significant effect on purchasing decisions.

\section{METHODS}

\subsection{Population and Sample}

The research population is a waste bank in the city of Semarang which produces creative industrial products. By using purposive sampling, 33 waste banks were obtained as research samples.

\subsection{Variables and Measurements}

Word of mouth is a marketing activity carried out on a product so that consumers talk about, promote and are willing to sell our products to others [13]. Word mouth promotion variable indicator consists of: the willingness of consumers to talk about positive things about product quality to others, recommend the product to others, and encourage others to repurchase the product [18]

Product differentiation is a company's effort to offer its products to customers at a better value, faster and cheaper than competing products [6]. Indicator variable product differentiation consists of: the products offered have benefits for consumers, the products offered have advantages over competitors, the products offered have a unique product image [6].

Purchase decision is a process of problem solving consisting of analysis needs and desires, information searching, assessment of selected sources on buying alternatives, purchase decision, and post-purchase behavior [6]. Purchase decision indicator consist of considerations in buying, conformity of attributes with wants and needs stability in buying [6].

\subsection{Data Analysis}

The variable data obtained in this study were analyzed using the Partial Least Square (PLS). PLS has become a trend for researchers as an alternative because it has looser requirements and is easy to understand [19]. PLS does not depend on the assumption of normality because it is a non-parametric statistic [20]. At the stage of assessing the measurement model (outer model), the convergent validity of the loading factor value of each indicator is required to be above 0.7 , the reliability test of the rho_A value and construct reliability (CR) is above 0.7 and the Average Variance Extracted (AVE) is above 0.5. The discriminant validity test based on the AVE root value is required to be greater than the correlation between constructs [20]. The structural model is evaluated by the value of T-statistics, which must be above 1.96 or probability below 0.05 for the acceptance of the one-tailed hypothesis [20,21]. 


\section{RESULTS AND DISCUSSION}

The results of data analysis in this study are divided into two, namely the measurement model testing and structural model assessment, which were carried out with the SmartPLS [22]. To test the measurement model, this study assessed the value of loading factor, Cronbach's Alpha, rho_A, construct reliability (CR), and average variance extracted (AVE), and correlation between variables. The test results of the measurement model (outer model) can be explained in Figure 1.

The results of the convergent validity test in Figure 1 , it can be explained that all indicators in the model have a loading factor above 0.7 . The reliability test results in Table 2 are declared eligible because the Cronbach's Alpha, rho_A and Construct Reliability values are above 0.7 and the Average Variance Error is above 0.5 . These results confirm that all indicators have met the validity and convergent reliability, which indicates that they are able to measure the construct and have good consistency. The test in Table 2 explains that the AVE root value is greater than the correlation between research variables which means it has met the discriminant validity test [20].

Based on the previous model testing, it is can be continue to hypothesis testing. This study uses bootstrap, a nonparametric procedure that allows testing the statistical significance of various PLS results such as path coefficients and R2 [23]. At this stage, the bootstrap method was chosen with a subsample of 5000 and a one-sided test significance of $5 \%$, in order to obtain stable results. The results of the hypothesis testing are shown in Table 3.

Based on the results of the calculation of direct effects in Table 3, it can be seen that path coefficient value is positive 0.522 , the $\mathrm{T}$-statistical value is 4.255 above T-table 1.96, and P-value is 0.001 below 0.05 . Based on these values, hypotheses 1 is supported by empirical data so that they can be accepted. This finding explains that word mouth promotion has a positive and significant effect on purchasing decisions. There are many factors that drivers the purchase decision. Based on the research data analysis, the study found that wordof-mouth promotion has a positive influences on purchasing decisions in handicrafts produced by the creative industry in the waste bank of Semarang City. It means that if a consumer encourages others to repurchase industrial products, it will increase the purchase decision. It is a marketing activity which a consumer willing to promote our products to other [13]. This result supported some previous research which concluded word of mouth was positively influence on purchase decision $[7,16]$.

Furthermore, Table 3 show that the effect of product differentiation on purchase decision have estimate positive 0.403 , t-statistic is $3.447>\mathrm{t}$-table 1.96 , and probability value is $0.000<0.05$. Based on these results, hypothesis 2 is accepted, that explain product differentiation has a positive and significant effect on purchasing decisions. Current research proved that differentiation product can effect purchase decision, which means the increasing of differentiation product is more likely to increase the purchase decision. A benefit, advantages and unique product will be more superior to competitor [10]. This result consistent with the previous results which concluded that product differentiation has positive effect on purchase decision $[11,17]$.

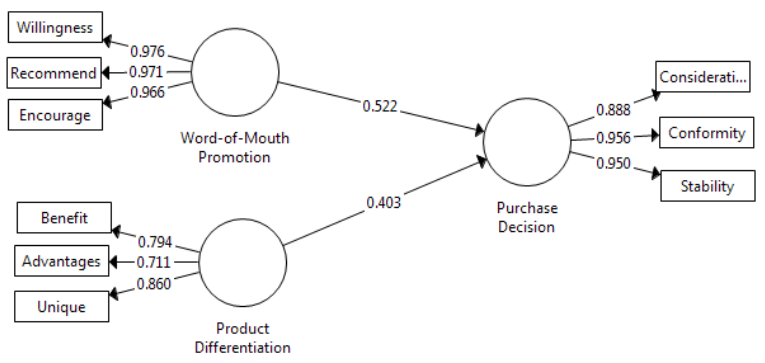

Figure 1 Calculate Estimate Result

Tabel 1 Reliability Result

\begin{tabular}{|l|c|c|c|c|}
\hline \multicolumn{1}{|c|}{ Variables } & $\alpha$ & $\rho$ & CR & AVE \\
\hline Word of Mouth & 0.970 & 0.972 & 0.980 & 0.943 \\
\hline Product Differentiation & 0.752 & 0.903 & 0.833 & 0.625 \\
\hline Purchase Decision & 0.923 & 0.927 & 0.952 & 0.868 \\
\hline
\end{tabular}

Table 2 Discriminant Validity Test Results

\begin{tabular}{|l|c|c|c|}
\hline \multicolumn{1}{|c|}{ Variables } & X1 & X2 & Y \\
\hline $\begin{array}{l}\text { Word Mouth Promotion } \\
(\mathrm{X} 1)\end{array}$ & 0.971 & & \\
\hline $\begin{array}{l}\text { Product Differentiation } \\
(\mathrm{X} 2)\end{array}$ & 0.582 & 0.791 & \\
\hline Purchase Decision (Y) & 0.756 & 0.706 & 0.932 \\
\hline
\end{tabular}

Table 3 The Hypothesis Testing

\begin{tabular}{|l|c|c|c|}
\hline \multicolumn{1}{|c|}{ Relationship } & Est. & T Stat. & $\mathrm{P}$ \\
\hline $\begin{array}{l}\text { WoM } \rightarrow \text { Purchase } \\
\text { Decision }\end{array}$ & 0.522 & 4.255 & 0.001 \\
\hline $\begin{array}{l}\text { Product } \\
\text { Differentiation } \rightarrow \\
\text { Purchase Decision }\end{array}$ & 0.403 & 3.447 & 0.000 \\
\hline $\mathrm{R}^{2}$ & 0.679 & & \\
\hline
\end{tabular}




\section{CONCLUSION}

The results of the analysis showed that the word of mouth and product differentiation have positive effect on purchase decision of handicrafts produced by the creative industry in the waste bank of Semarang City. All parties concern should give attention to creative industry from waste bank because waste bank also has advantages in environment, health and empowerment. Local government could help by accept the product for government necessity, private sectors could help to promote the products and financial support, and university could support by research and community empowerment..

\section{ACKNOWLEDGMENTS}

I would like to thanks of gratitude to Director of Resource, Ministry of Education, Cultural, Research and Technology as funding source for this research.

\section{REFERENCES}

[1] Z. Zahara, Role of resource-based entrepreneurship development to increase competitiveness of traditionally woven sarong creative industry, Russian Journal of Agricultural and SocioEconomic Sciences, vol. 67, pp. 121-128, 2017.

[2] I. N. Jelita. (2021, 05-10-2021). Ekonomi Kreatif Sumbang PDB hingga Rp1.100 T. Available: https://mediaindonesia.com/ekonomi/377881/ekon omi-kreatif-sumbang-pdb-hingga-rp1100-t

[3] N. Kariada, T. Martuti, and A. B. Setiawan, Kajian Kebijakan Pemerintah Kota Semarang Dalam Pengembangan Ekonomi Kreatif, Jurnal Riptek, vol. 12, pp. 131-142, 2019.

[4] S. Wulandari and P. F. Alam, the Use of Online Waste Management System, Ecotrophic, vol. 12, pp. 185-197, 2018.

[5] P. Kotler and G. Armstrong, Dasar-Dasar Pemasaran: Principles of Marketing. Jakarta: Intermedia, 2013.

[6] P. Kotler, Riset Pemasaran dan Perilaku Konsumen: Jakarta: PT Gramedia Pustaka Utama, 2000 .

[7] I. R. Finanda and A. Wiwaha, Pengaruh word of mouth dan brand image terhadap keputusan penggunaan salon kecantikan pada konsumen Miloff Beauty Bar, E-Journal Widya Ekonomika, vol. 1, pp. 134-140, 2018.

[8] F. Ayuningsih and I. Maftukhah, The Influence of Product Knowledge, Brand Image, and Brand Love on Purchase Decision through Word of Mouth,
Management Analysis Journal, vol. 9, pp. 355-369, 2020.

[9] R. Rachman and T. W. Abadi, Komunikasi word of mouth dan keputusan pembelian batik Bangkalan, Jurnal Aspikom, vol. 3, pp. 285-295, 2017.

[10] A. Gandhy and J. A. Hairuddin, Analysis of Promotion and Product Differentiation of Jukajo on Consumer Purchase Decision, Binus Business Review, vol. 9, pp. 9-18, 2018.

[11] M. Rahman and N. Suhayani, Analisis Differensiasi Produk dan Citra Merek terhadap Keputusan Pembelian Konsumen pada Sepeda Motor Merek Yamaha Mio di Kota Langsa, Jurnal Samudra Ekonomi Dan Bisnis, vol. 11, pp. 227 236, 2020.

[12] D. A. Harahap, D. Amanah, and F. Agustini, Effect of product completeness and price on consumer purchasing decision in smes market medan, Jurnal Manajemen, vol. 22, pp. 47-61, 2018.

[13] M. S. Sumardy and M. Melone, The power of word of mouth marketing, 2011.

[14] P. Purwanto and Z. L. Sukirono, Komunikasi Bisnis (Perspektif dan Kultural). Yogyakarta: Pustaka Pelajar, 2014.

[15] A. Sernovitz, G. Kawaski, and S. Godin, Word of mouth marketing: Dearborn Trade, A Kaplan Professional Company, 2006.

[16] S. C. Lotulung, J. Lapian, and S. Moniharapon, Pengaruh kualitas produk, harga, dan wom (word of mouth) terhadap keputusan pembelian handphone evercoss pada cv. tristar jaya globalindo manado, Jurnal EMBA: Jurnal Riset Ekonomi, Manajemen, Bisnis dan Akuntansi, vol. 3, pp. 817826, 2015.

[17] N. F. Simamora and E. Y. Situmeang, Analisa Pengaruh Diferensiasi Produk Terhadap Keputusan Pembelian Konsumen pada Showroom Garuda Sibolga, Juripol (Jurnal Institusi Politeknik Ganesha Medan), vol. 1, pp. 68-79, 2018.

[18] B. J. Babin, Y. K. Lee, E. J. Kim, and M. Griffin, Modeling consumer satisfaction and word-ofmouth: restaurant patronage in Korea, Journal of Services Marketing, 2005.

[19] J. F. Hair Jr, G. T. M. Hult, C. Ringle, and M. Sarstedt, A primer on partial least squares structural equation modeling (PLS-SEM): Sage Publications, 2016.

[20] J. F. Hair Jr, G. T. M. Hult, C. M. Ringle, and M. Sarstedt, PLS-SEM Book: A primer on partial least 
squares structural equation modeling (PLS-SEM) (edr Ed.): Sage publications, 2021.

[21] H. Latan, R. Noonan, and L. Matthews, Partial least squares path modeling, Partial least squares path modeling: basic concepts, methodological issues and applications, 2017.
[22] C. M. Ringle, S. Wende, and J.-M. Becker, SmartPLS 3. SmartPLS vol. 10: GmbH, Boenningstedt, 2015.

[23] J. F. Hair Jr, M. Sarstedt, C. M. Ringle, and S. P. Gudergan, Advanced issues in partial least squares structural equation modeling: SAGE Publications, 2017. 